\title{
Communicating hope with one breath
}

Author:

Stephen D. Edwards ${ }^{1}$

Affiliation:

${ }^{1}$ Department of Psychology, University of Zululand,

South Africa

Correspondence to:

Stephan Edwards

email:

sdedward@telkomsa.net

Postal address:

3 Antigua, 32 Chartwell

Drive, Umhlanga Rocks

4320, South Africa

Dates:

Received: 25 June 2010

Accepted: 11 Oct. 2010

Published: 07 Mar. 2011

How to cite this article:

Edwards, S.D., 2011,

'Communicating hope with

one breath', HTS Teologiese

Studies/Theological Studies

67(2), Art. \#901, 7 pages.

DOI: $10.4102 /$ hts.v67i2.901
(C) 2011. The Authors. Licensee: OpenJournals

Publishing. This work is licensed under the Creative Commons Attribution License.
The central thesis of this article was that the phenomenon of hope involves states and stages of consciousness development, which can be enhanced through breath control, meditation, prayer and related practices that have formed the essence of various spiritual healing traditions for millennia. In particular, it was argued that breath control can provide a vital foundation for consciousness transformation and the development of hope. Whilst breath control alone may lead to a state of pure, transcendent and/or cosmic consciousness, the practical theological implications are that its effect of enhancing states and stages of consciousness may be anchored and amplified. This process can take place through further contemplative and intercessory meditation, prayer and related behaviour and will differ between people, groups, contexts, religious and/or spiritual traditions. A particular method of breath control called One Breath, which is associated with pure consciousness and the experience of hope was described. Such an experience typically leads to further spiritual practice, healing and transformation. It was concluded that such ongoing spiritual practice is crucial for improving consciousness development, healing and hope for individuals, societies, planet Earth and the cosmos.

\section{Introduction}

In spite of (some might say because of) extensive developments in technology, the natural sciences, modern biomedicine and many other fields, contemporary existence on planet Earth remains plagued by human suffering, illness (particularly the HIV and AIDS pandemic), violence (international terrorism for example), crime, overpopulation, ecological crises and a host of other problems. Some of these problems seem to have changed very little over the centuries. Many give up in the face of what may seem insurmountable obstacles. Is there any hope?

The rather provocative title was deliberately chosen to highlight the various practical theological intentions of this article, which can be unpacked as follows:

- It is concerned with the communication of hope and related states of consciousness and experiences such as trust, faith, integrity and love.

- It reflects the faith that such experiences are most meaningfully grounded in and directed by spiritual practice.

- A form of breath-based spiritual healing called One Breath will be discussed.

- On the basis of such practice, evidence will show that the state of consciousness called hope may be enhanced through one particular form of breath. In practical terms this is experienced as one, long, slow, relaxed and/or apneustic breath whereby hope is enhanced through the feeling of being at one with the eternally infinite present here and now.

- There is specific focus on the communication of hope through breath, meditation, prayer and related experiences such as pure consciousness, faith and love.

In order to realise these intentions, the article explores the phenomenology of hope within the context of various ancient and modern spiritual and psychological healing traditions. These traditions include ancestor reverence, Hinduism, Taoism, Buddhism, Christianity and Islam as well as psychotherapeutic systems such as psychoanalysis, cognitive behavioural therapy and family therapy. All of these systems converge in the recognition, validation and provision of evidence for insight, consciousness, peak experiences and therapeutic moments as being valuable precipitants in effecting healing changes (Corsini 1989; Ivey, Andrea, Ivey \& Simek Morgan 2002; Wilber 1977, 2000, 2007). In addition to its bias in terms of the author's African, Christianorientated background, occupation as psychologist, lifelong interest in human spirituality and ongoing personal, spiritual practice, this article is particularly informed by the work of Ken Wilber, who is receiving increasing recognition in the field of practical theological literature (Ferreira 2010:1-8).

By definition, practical theology refers to that descriptive, empirical, pragmatic, interpretive and normative field where religious traditions meet contemporary experience in transformative 
activity (Osmer 2008:34; Woodward \& Patterson 2000:1-22). This article is concerned with a practical theological, spiritual and psychological exploration into the phenomenology, communication and improvement of that special state of consciousness experienced as hope. It is psychological in the sense conveyed by the original broad meaning of the term as the study and use of the breath, soul or spirit of life that leaves a person at death and continues in some other form. The great chain or nest of being and/or consciousness ranges from matter to body to mind to soul to spirit and vice versa, depending upon whether this chain is being viewed from an evolutionary or involutionary perspective. In terms of this chain of being, this article is particularly concerned with phenomena arising at the level of soul and spirit. Here, soul is defined as an individual, incarnated expression of spirit and spirit as the universal expression of soul (Hergenhahn 2001:1-80; Judith 2004:13; Wilber 2000:106-108).

\section{Hope as a state of consciousness}

The phenomenon of hope has long been of interest to psychologists. For Erikson (1963:247-250), the experience of hope marked the successful resolution of the first stage of ontogenetic development with its accompanying psychosocial crisis of trust versus mistrust. More recently, hope has formed a conceptual pillar of the positive psychology movement away from the so-called pathogenic model to a more salutogenic or fortigenic focus on human resilience, strengths, resourcefulness and life skills. This is evidenced in the design and evaluation of hope programmes (Pretorius, Venter, Temane \& Wissing 2008:301-310). Whilst most research typically views hope from a dynamic, intrapsychic perspective as an intrapersonal phenomenon, or at the level of individual soul, if we examine hope from a transpersonal, spiritual perspective, a further, bigger picture emerges. Writing from this perspective, Wilber (1977:105-141) has noted four typical human dualisms: subject-object (personworld), being-nonbeing (life-death), body-mind and egoshadow. All of these require integration before a state of pure consciousness can be fully realised. If we view hope as a state and/or stage of consciousness, it implies both correlational and inferential relationships. That is to say, states and/or stages of pure, prereflective, transcendent, cosmic, unitary and/or non-dual consciousness will be both associated with, as well as lead to further, optimal experiences of hope.

Such a state of pure consciousness has been variously described in the spiritual wisdom traditions as reflecting the source, context, ground and goal of all Being, Tao, Brahmin, God, Allah and so on. Wilber (1977:37-69, 2000:8, 2007:68-69) has referred to this as that which is always already arising, moment to moment, in non-dual union of emptiness and form, which follows earlier experiential stages of nature, deity and formless mysticism. In Christian terms, for example, this non-dual consciousness may be described as a feeling of being with that which was in the beginning, is now and will be forever; a mystical, contemplative Christian experience of oneness with Christ, the Trinity and/or the Godhead. This is made possible through the life and death of the Christ.
In Wilber's basic integral framework of psychology and spirituality, such a state of consciousness will become a more enduring, stable stage, to the extent that it is realised from various perspectives. This includes subjective, intersubjective and objective dimensions or first, second and third person terms. Alternatively, spirituality may become unbalanced through the over-emphasis on any perspective to the exclusion of others. For example, Spirit in the first person has been described as the great I or Witness of every moment, as great radiant You, Thou or We immediately revealed in sacred communion in the second person and in the third person as the Great It, Isness, Thusness and Suchness of every context. Wilber (2007:158-161) notes that the theistic traditions that typically espouse second person experiences have tended to become very uncomfortable with first person experiences, resulting for example in the crucifixion of Jesus. Similarly, contemporary New Age spiritual movements may tend to neglect first or second person spirituality if third person, Gaia, Web of Life or ecosystemic views are too exclusively extolled.

Whilst such a state of pure consciousness, alluded to by various spiritual, wisdom and healing traditions, is ultimately indescribable in language, logic or numbers, the enhanced consciousness aspects of the experience are neatly captured in Travis and Pearson's (2000) research into its phenomenological and physiological correlates. The phenomenological experience has been described by experienced meditators as a peaceful, unbounded state, characterised by an absence of time, space or body sense. Physiological correlates converge in terms of periods of relaxation and breath suspension, either in the form of breath retention or apneustic breathing, characterised by long slow in-breaths of more than 10 seconds duration.

\section{Practical Theological implications of breath control}

Whilst breath control alone can lead to a state of pure, transcendent and/or cosmic consciousness, the practical theological implications are that its effect of enhancing states and stages of consciousness may be anchored and amplified further. This takes place through contemplative and intercessory meditation, prayer and related behaviour and will differ between people, groups, contexts, religious and/or spiritual traditions. In depth investigations into transformations of consciousness associated with major spiritual traditions have indicated common developmental stages. For example, in Christianity such stages are referred to as: image (any persons God given, natural reality), metanoia [conversion], apatheia [purification or conversion], light [illumination and insight] and theosis [union with God/ Godhead] (Wilber 2000:210-211, 2007:79-81; Wilber, Engler \& Brown 1985:300-301). The practical theological mission and message of this article is one of transformation of consciousness through breath control, meditation and prayer in order to provide hope and healing for humanity, society and cosmos. The article is a sequel to an earlier contribution, which explicated practical theological, psychological, 
phenomenological, contextual and empirical perspectives on a breath-based apprehension of the Holy Spirit (Edwards 2009).

\section{One Breath as a form of breath-based spiritual healing}

A primary ethical obligation for all healing is to make whole, to transform from illness to health, to bring together and renew that which was fractured, broken or disordered and to integrate disparate parts. The phrase 'One Breath' has been used by Joy Manne (1999), in her excellent article on Buddhist breath work and the nature of consciousness. As used in this article, it has further additional meanings related to the experience of pure consciousness in relation to the primordial Spirit, characterised by immaterial emptiness, luminous awareness and infinite energy (Reid 1998:256). During meditation, the breath becomes increasingly slow, soft and stilled until there is the experience of being breathed by One Original breath. This is an integrating and healing experience. Healing One Breath practice will be described in detail in the section that follows.

The fundamental role of the breath in healing has timehonoured traditions. Over many centuries, indigenous healers in Africa, India, China and other areas of planet Earth have practised various forms of breath-based spirituality. Healing traditions variously extol a form of breath-energy called $R a$ and $K a$ (Ancient Egypt), N/um (San), Umoya (Zulu), Elima (Congolese), Ruach Ha Kodesh (Hebrew), Prana (Hindi), Nafas Ruh (Moslem), Baraka (Sufi), Spiritus Sanctus (Latin), Pneuma (Greek), Chi (Chinese), Mana (Figian), Ni (Sioux), Manitu (Alonquin), Chindi (Navajo) (Myers 1993:24; Elinwood 2004:23; Reid 1998:90-94; Taub-Bynum 1984:55-56). This healing energy is typically experienced through what Jung (1957:46) has referred to as the 'breath-body' or 'spirit body.' Sitting still, standing and moving forms of breath co-ordinated behaviour may be viewed as providing a foundation for all forms of healing and transcendence as exemplified in alpha conditioning, biofeedback, transcendental meditation, ! Kung healing dance and Tai chi (Edwards 2008:142; Reid 1998:181199). Healthy breathing experiences that have been bodily re-experienced as anchors, provide a phenomenological foundation for various forms of imagery:

- light, sound, colour, touch and movement used in breathwork

- expressive therapy

- progressive relaxation

- systematic desensitisation

- crisis intervention

- other forms of holistic psychological caring

- counselling

- psychotherapy

- illness prevention

- health promotion

- ultimate spiritual healing (Edwards 2008:152; Ivey, D'Andrea, Ivey \& Simek-Morgan 2002:129-152).

The power of such breath-based healing becomes amplified in the context of any spiritual tradition as exemplified in Christian Hesychasm breathing practices or Buddhist breathing techniques. For example, contemporary indigenous Zulu healing is based on the spiritual energy of the ancestors. This energy takes different forms as reflected in ukububula/ nokubhonga kwedlozi, the religious, spirit-power and supernatural force of the ancestors breathing through the Zulu divine-healer [isangoma]. Ancestors are experienced as the living-dead, continuing to care for descendents in an extended link going back to the First Cosmic Breath of Creation. During her (or, in rare cases, his) spiritual calling the Zulu divine healer is breathed by recently departed ancestors appearing to her in dreams, calling her to become a diviner and accompanying her through a spiritual rebirth experience until completion of her apprenticeship under a qualified diviner in a macro-process called ukuthwasa. Thereafter she experiences being breathed by the ancestors during the divine healing process.

Spiritual healing power [umoya] is mobilised in African Indigenous Churches (AIC) as members dance around in a circle chanting 'woza umoya, woza umoya' [come spirit come]. More formal meetings are held in churches, community halls or private homes. Here, faith healers [abathandazi] or prophets [abaprofethi] may close windows and doors to keep out distractions and amplify spiritual breath energy for a time of intense individual, family or community healing and spiritual purification [ukuhlambulula]. This takes place in a religious ceremony that includes rituals, music, drama and dance. Faith healers typically require their clients to breathe the Holy Spirit [Umoya oNgcwele] and to drink and pray over holy water [isiwasho] (Oosthuizen, Wessels, Edwards \& Hexam 1989:119-181).

Similar spiritual themes occur in various major spiritual traditions. From the Judaic perspective, Genesis 2:7 reads 'The Lord God formed the man from the dust of the ground and breathed into his nostrils the breath of life and the man became a living being'. In Hindu Yogic and Taoist Chigung traditions, pranayama and chi-gung respectively refer to various forms of breath-energy skills. One particular branch of Buddhism, Zen, places great emphasis on the lifebreath. In Zen breathing techniques, special emphasis is on breathing as a grounding and meditation technique, through life-breath stored in the energetic, intestinal area of the belly. This is referred to in India as the third chakra or manipura, in China as the lower tantien and in Japan as the hara. Another Buddhist breathing technique is to walk barefoot on the grass, in grateful consciousness of all previous ancestral beings beneath one's feet. In Christianity, John 20:21 reads:

Again Jesus said, 'Peace be with you! As the father has sent me, I am sending you.' And with that he breathed on them and said, 'Receive the Holy Spirit'.

Various stages and levels of spirituality are outlined in the Islamic mystical tradition of Sufism. The term nafs refers to a process involving the breath, essence, self and nature of the incarnated soul in its quest to return to the realm of spirit through ultimately perfected nafs bringing the realisation that individuality and separateness are illusions and that only God exits (Edwards 2008:139; Reid 1998:160-180) 
A famous founding father of phenomenological, behavioural and functionalist schools of thought in psychology, lauded for his work on philosophy and the varieties of religious experience, William James once remarked that the stream of consciousness was only a careless name for what, when scrutinised, revealed itself to consist chiefly in the stream of his own breathing (James 1890:239). As implied in all the spiritual healing traditions mentioned above, with practice, this individual, introspective insight becomes infinitely amplified in the ultimate experience of being breathed by pure Consciousness as connoted in the phrase 'One Breath.' This personal and transpersonal, integrating and healing experience provides infinite energy for all healers in their commitment to care for people and contexts requiring healing.

\section{One Breath practice}

The basic form of One Breath practice involves sustained focus on relaxed breathing. Keeping on observing the breath and monitoring bodily experiences, one continually lets go all feelings and thoughts with deeper and deeper relaxation. After a while the breath becomes increasingly slow, still, silent, smooth, soft and stable. Sustained focus on deepening this state of relaxed breathing, continually letting all else go and witnessing whatever arises in moment to moment awareness will eventually lead to the experience of being breathed, rather than breathing. One Breath fundamentally refers to this simple, momentary experience of being breathed. Whilst it may not initially be easy to block out personal contexts of suffering, care, pain, crisis or other related circumstances, such an experience is available to everyone and deepens with practice. If one creates time, the easiest way to begin practice is immediately after waking up in the morning.

A fundamental form of practice is to focus consciousness on belly breathing. Keeping still, one should relax and observe the movement of the belly just below the navel. This may be very difficult initially, but becomes easier with practice. It may help to place one hand on the belly just below the navel. Various sensations, feelings, thoughts and experiences will initially drift in and out of consciousness. These will become less distracting with continual returning of focused consciousness to belly breathing and after a while there will be pure consciousness. One Breath cannot be forced, but simply happens. This particular practice forms the foundation for various methods of relaxation, meditation and prayer, which focuses on breathing through the belly area, also known respectively in Yogic, Taoist and Zen traditions as manipura, tan tien and hara. Training typically focuses on the reflection of converging consciousness through one point awareness. Practice contexts vary depending upon the particular spiritual tradition, as in the following examples that have produced healing effects in the author's professional occupation as teacher, researcher and psychologist offering breath psychotherapeutic workshops (Edwards 2008:157-161, 2009:255). At all levels of practice the emphasis is on remaining with the natural breathing pattern and it is extremely important that practitioners say within their individual comfort zones, especially with regard to their health status and particular religious and/or spiritual inclination and/or persuasion.

One particular valuable form of a Christian-orientated One Breath contemplative prayer, which follows a centring period of silence and relaxed breathing, is for people to tune into their heart rates during each cycle of breathing in and breathing out. Once a comfortable, relaxed rhythm is established, the breathing pattern can be complemented with any images, words, phrase or sentences. For example, in the sentence 'I am with I AM when we are with Jesus Christ', the phrase 'I am with I AM when we are' may be repeated in synchrony with an eight heartbeat out-breath and 'with Jesus Christ' repeated to a four heartbeat in-breath pattern respectively, during an ever deepening state of consciousness. Keating (2009:11-160) provides in depth instruction on such contemplative practice. Previous empirical research indicated highly significant quantitative and qualitative improvements in spirituality perceptions and experiences of 59 participants following Christian-orientated African breath-based psychotherapeutic workshops as compared with a waiting list control group of 41 people (Edwards 2009:81-98).

In Yogic traditions, further One Breath practice may be based on conscious experience related to the in-breath, outbreath and breath retention, respectively known in yoga as puraka, recaka, antara kumbhaka and bahya kumbhaka. From a physiological perspective, every out-breath is associated with the relaxing parasympathetic division of the autonomic nervous system and every in-breath to the stimulating sympathetic division. Therefore, longer out-breaths increase relaxation and longer in-breaths stimulation. This is extremely valuable experiential knowledge in regulating one's arousal and energy levels.

Another example in the Transcendental Meditation tradition relates to apneustic breathing. Again, this is preceded by relaxed abdominal respiration. Although it can be done in any posture, the best initial way is to relax fully whilst lying on one's back (savasana) and focusing consciousness on diaphragmatic belly breathing until this becomes even and regular. Breath is the bridge between body and mind. Once the breath becomes stable and stilled, a calm state of mind is induced and it becomes possible to count heart beats in order to monitor length of in- and out-breaths. Breathing rate is approximately one quarter that of heart rate. For enhanced relaxation, a good rule is to double the length of the outbreath in relation to the in-breath, whilst gradually slowing the breathing rate.

After about 10 breath cycles at this rate, the pattern becomes automatic. Physiologically, this change is associated with decreasing central nervous and reticular arousal system activity as consciousness descends to the medullar region of the brain stem responsible for respiration, heart-rate and blood pressure. This increased relaxation associated with decreased respiration, heart rate and blood pressure is a valuable precursor for any form of meditation and or contemplation. 
Increasingly stressful human life-styles associated with contemporary existence on planet Earth will benefit greatly through daily 15 minute practice of such a breathing pattern, whether or not this is enhanced by further formal meditation or prayer.

From this base, it becomes easy to practice the apneustic breath by simply slowing down the breathing further to $10-15$ heart beats for both in- and out-breaths, with or without very brief periods of breath retention and witnessing whatever arises in the consciousness. With increasing practice, the whole breathing, consciousness and experiential pattern will become automatic and deeper and more meaningful levels of consciousness will accrue. Extensive research with experienced meditators has conclusively established the health benefits of long term meditation (Wilber 2001, 2007). The value of even one long slow, silent, smooth breath is the basis of everyday popular wisdom as reflected in the Zulu phrase 'ukhukhokh umoya' ['take a deep breath' or 'take a breather']. It is important to make the distinction between an over-breath and the relaxed diaphragmatic breath. The former is associated with hyperventilation that can occur through stressful clavicular and thoracic breathing and the latter with what research has established as the relaxation response (Benson, Beary, \& Carol 1974:37). Practicing in long, slow apneustic breathing will bring the associated deep, meaningful levels of conscious experience and realisation of states and stages of pure consciousness termed One Breath.

One Breath is always available in infinite, eternal presence. Further, life-long practice in both still and moving forms may lead to its constant consciousness. For example, a still sitting form could include a transcendental meditation in siddhasana posture repeating a One Breath 'aum' mantra or a One Breath energy circulating microcosmic orbit meditation. One Breath practice is enhanced through various yogic or chi-gung standing postures. Moving practice may involve the cultivation of One Breath stillness in pure consciousness during the sun salutation (surya namaskar), Eight Brocades or Tai Chi. Finally, One breath extends beyond meditation and prayer in its ultimate reality.

\section{Communicating hope}

Examples of communicating hope abound in literature on breathing, meditation, prayer and healing. The seven quotations that follow have been chosen for their practical facility to respectively communicate healing, breath, meditation, pure consciousness, oneness, hope and love in any practical theology curriculum. They reflect various spiritual, wisdom and or religious traditions.

\section{Quotation 1}

'Woza moya, woza moya' (African Indigenous Church (AIC) circular healing dance chant of 'come spirit, come spirit').

This quotation will be familiar to any AIC member as well as observers of AIC meetings wherever these are held: on mountains, at the sea or river. It is instructive in its revelation of ancestral consciousness with special reference to the Holy Spirit (Edwards 2009:81-98).

\section{Quotation 2}

We give many names to God even though He is One. The same is true of energy. There is nuclear energy, electrical energy, muscular energy and mental energy. All these are vital energy or life energy, called in Sanskrit, pranic energy or simply, prana. Prana is called Chi in China and Ki in Japan. Some suggest that the nearest traditional concept of prana in the West is the Holy Spirit of Christianity, a sacred power that is both immanent and transcendent ... Prana is usually translated as breath, yet this is only one of its many manifestations. According to the Upanishads, it is the principle of life and consciousness. It is equated with the soul (Atman). It is the breath of life of all beings in the universe. They are born through it and live by it, and when they die their individual breath dissolves into the cosmic breath. It is the most essential, real and present feature of every moment of our lives and yet it remains the most mysterious. It is Yoga's job, and especially pranayama's, to enter onto the heart of this mystery. Prana in the form of breath is the starting point ...

(Iyengar 2005:65-66)

The value of this quotation lies in its clarity of interpretation with regard to both the physical energising effect of breath as a primary form of nourishment and relationship with the environment as well as a key to more subtle dimensions involved in meditative breathing as recognised in Hindu, Buddhist, Christian and other traditions.

\section{Quotation 3}

I do a breathing technique, alternate nostril breathing, pranayama prior to meditation. When meditating I don't think about breathing at all - it actually stops in fact or settles to such an extent that sometimes you wonder if you are breathing. The breath is so fine. It is not a conscious effort to arrive at that state - its just a by product of relaxation. I like to meditate at least once a day. Meditation means a state of non-conditional peace. It is not linked to any particular doctrine experiencesby that I mean one loses a sense of boundaries- then after the meditation one feels very relaxed, positive and in tune with life. I started with a Transcendental Meditation group, was initiated by a teacher into the technique, who said it was free of religion and philosophy- the founder is a Hindu, so perceptions in the teaching of this technique are related to this world view. As your breath becomes finer - consciousness transcends itself. You slip beyond conscious thinking into 'eternity' or unity with the 'absolute'. That is the basis of the philosophy- that there is an absolute reservoir of creativity and intelligence underlying material life. You only know that you have experienced it and cannot verbalise it - simply know that you have been 'there' a period has passed that you cannot count; it's an experience of bliss and sometimes it's only for a fraction of a second that you have dipped into it. You can't force it, it comes when you least expect it. You cannot anticipate its coming, but even if it does not happen, the type of psychic rest you obtain is quite extra-ordinary. It's been demonstrated here at university - for weeks when I don't meditate I get depressed. One just needs to meditate once and suddenly one's take on life improves.

(University colleague, personal communication)

This quotation by a university colleague succinctly communicates the value of a Hindu pranayama techniqueineliciting psychological and spiritual transformations of consciousness. 


\section{Quotation 4}

that blessed mood

In which the burthen of the mystery,

In which the heavy and the weary weight, Of all this unintelligible world

Is lightened:- that serene and blessed mood, In which the affections gently lead us on Until the breath of this corporeal frame And even the motion of our human blood Almost suspended, we are laid asleep In body and become a living soul; While with an eye made quite by the power Of harmony and the deep power of joy, We see into the life of things...

And I have felt

A presence that disturbs me with the joy

Of elevated thoughts; a sense sublime

Of something far more deeply infused

Whose dwelling is the light of setting suns

And the round ocean and the living air

And the blue sky and in the mind of man

A motion and a spirit that impels all thinking things

All objects of all thought

And rolls through all things

(Wordsworth's Lines composed a few miles above Tintern Abbey on Revisiting the Banks of the Wye during a Tour)

Wordsworth's poem in this quotation are often used as examples of pure consciousness in the transcendental meditative traditions, as well as a form of nature mysticism that may facilitate deity, causal and non-dual consciousness transformations (Travis \& Pearson 2000:77-89; Wilber 2000:14, 2007:93).

\section{Quotation 5}

I pray also for those who will believe in me through their message, that all of them may be one, Father, just as you are in me and I am in you. May they also be in us so that the world may believe that that you have sent me. I have given them the glory that you gave me, that they may be one as we are one. I in them and you in me. May they be brought to complete unity to let the world know that you sent me and have loved them even as you have loved me.

(Jn 17:20)

This quotation from St John's gospel immediately conveys Jesus' apprehension of and union with God, the Father, through original Christian contemplative and intercessory prayer.

\section{Quotation 6}

May the God of hope fill you with all joy and peace as you trust in him, so that you may overflow with hope by the power of the Holy Spirit.

$(\operatorname{Rm} 15: 13)$

Paul's letters involving this and the following quotations are often used in Christian circles for their practical facility to directly reveal the communication of hope and related states of consciousness and experiences such as trust, faith, integrity and love.

\section{Quotation 7}

'And now these three remain: faith, hope and love. But the greatest of these is love' (1 Cor 13:13).

\section{Conclusion}

The intention and vision of this article is an ancient one, as implied in all the time-honoured spiritual wisdom and healing traditions. The practical theological mission and message is one of personal and transpersonal transformation of consciousness through breath control, meditation, contemplation and/or prayer in order to transform and heal society and cosmos. The ensuing communication of hope is an essential foundation for such transformation. Hope is defined as a state of consciousness, which implies that the most favourable states of consciousness realise optimal experiences of hope and create the most advantageous conditions for its communication. The aim was that the text reflexively communicates and the reader apprehends, the vast theoretical scope and direct experiential value of including some form of breath based meditative, contemplative and/ or intercessory praxis in the curricula of practical theology.

During deep relaxation, breath control, meditation and prayer, the breath becomes increasingly slow, soft, silent, smooth, stilled and stable until there is the experience of being breathed by one original Breath. Although ultimately beyond language, logic or numbers, this non-dual experience is one of pure, transcendent and/or unity consciousness, profound relaxation, unbounded awareness and empty, luminous energy of the primordial Spirit as revealed in the various examples given above. Whilst it is recognised that such experience may simply refer to a transitory state of consciousness, the evidence from various spiritual healing and psychotherapeutic traditions is that one authentic glimpse of pure consciousness can lead to profound healing effects. It also typically leads to ongoing spiritual practice and further, deeper, more meaningful stages of hope through personal, social and spiritual transformation and healing.

Although breath control alone can achieve wonders, the effect is amplified through further contemplative and intercessory meditation, prayer and related healing action which will differ between people, groups and contexts. For example, ancestral breathing may include memorial to family members in an extended link going back to the First Breath of Creation. People of Muslim faith might focus on nafs progression and Allah. Christian breathing might include the Trinity of God as Father, Son and Holy Spirit, accompanied by images of Light, Love and Life. Buddhist breathing could involve meditation in clearing the mind to pure emptiness and beyond, possibly followed by a Lovingkindness meditation. People of Taoist persuasion could focus on the Way of harmonising the powers of heaven, earth and humanity.

In addition to the generation of such experiences as hope and love, conscious One Breath practice typically leads to helpful 
actions on behalf of other people and the environment at large. Such practice inevitably leads to hope for all sentient beings on planet Earth and the cosmos for the foreseeable future, because knowledge becomes conscious that each breath is a link to what has been called many names: God, the Absolute, Brahmin, Tao, Allah; of that reality which was, is and will be for ever. This One Breath is infinitely available.

\section{References}

Benson, H., Beary, J.F. \& Carol, M.P., 1974, 'The relaxation response', Psychiatry, Journal for the Study of Interpersonal Processes 37(1), 37-46.

Corsini, R.J., 1989, Current psychotherapies, F.E. Peacock, Itasca.

Edwards, S.D., 2008, 'Breath psychology: fundamentals and applications', Psychology and Developing Societies 20(2), 131-164.

Edwards, S.D., 2009, 'A breath-based apprehension of the Holy Spirit: practical theological, psychological, phenomenological and contextual perspectives', Practical Theology 24 (2), 81-98.

Elinwood, E., 2004, Qigong basics, Tuttle, Boston.

Erikson, E.H., 1963, Childhood and society, WW Norton and Co., New York.

Ferreira, I.W., 2010, 'Die ontwikkeling van die menslike bewussyn: Ken Wilber se AQAL - teorie', HTS Teologiese Studies/Theological Studies 66(1), 1-8.

lyengar, B.K.S., 2005, Light on life, Rodale, London.

Ivey, A.E., D’ Andrea, M., Ivey, M.B. \& Simek Morgan, L., 2002, Theories of counselling and psychotherapy: A multicultural perspective, Allyn and Bacon, Boston.

James, W., 1890, Principles of psychology, Henry Holt, New York.

Judith, A., 2004, Eastern body, western mind, Celestial Arts, Berkeley.

Jung, C.G., 1957, 'Commentary on "The secret of the golden flower"', in Sir H. Read, M. Fordham, G. Adler (eds.), transl. R. Hull, Executive Editor, W. McGuire, Collected Works of Jung, C.G., vol. 13, pp. 1-56, Bollingen Series XX, 20 volumes, Routledge and Kegan Paul, London, Princeton University Press, Princeton, 1953-1979.
Hergenhahn, B.R., 2001, An introduction to the history of psychology, Wadsworth Thomson Learning, Belmont.

Keating, T., 2009, Intimacy with God: An introduction to Cantering Prayer, Crossroads Publishing, New York.

Manne, J., 1999, 'Only one breath. Buddhist breathwork and the nature of consciousness', The Healing Breath 1 (1), 22-46.

Myers, L., 1993, Understanding an Afrocentric world view: Introduction to an optimal psychology, Dubuque, Kendal Hunt.

Oosthuizen, G.C., Edwards, S.D., Wessels, W.H. \& Hexam, I., 1989, Afro-Christian religion and healing in Southern Africa, Edwin Mellin, Lewiston.

Osmer, R., 2008, Practical theology: An introduction, Wm. B. Eerdmans, Michigan.

Pretorius, C., Venter, C., Temane, T \& Wissing, M., 2008, 'The design and evaluation of a hope enhancement programme for Adults', Journal of Psychology in Africa 18(2), 301-310.

Reid, D., 1998, Chi-Gung. Harnessing the power of the universe, Simon and Schuster, London.

Travis, F. \& Pearson, C., 2000, 'Pure consciousness: distinct phenomenological and physiological correlates of consciousness itself', International Journal of Neuroscience 100, 77-89.

Taub-Bynum, E.B., 1984, The family unconscious, Quest Books, Wheaton.

Wilber, K., 1977, The spectrum of consciousness, Quest, London.

Wilber, K., 2000, Integral psychology, Shambhala, Boston.

Wilber, K., 2001, The Eye of Spirit, Shambhala, Boston.

Wilber, K., 2007, Integral spirituality, Integral Books, Boston.

Wilber, K., Engler, J. \& Brown, D.P. (1985), Transformations of Consciousness: Conventional and contemplative perspectives on development, New Science Library Shambhala, Boston.

Woodward, J. \& Patterson, S., 2000, The Blackwell reader in pastoral and practical theology, Blackwell, Oxford. 